Research Article

\title{
Performance of Super-Large-Span Tunnel Portal Excavated by Upper Bench CD Method Based on Field Monitoring and Numerical Modeling
}

\author{
Yanbin Luo, ${ }^{1}$ Jianxun Chen ${ }^{D}$, ${ }^{1}$ Zhou Shi, ${ }^{1}$ Shaoqiang Zhang, ${ }^{2}$ Weiwei Liu, ${ }^{1}$ Yao Li, ${ }^{1}$ \\ and Lijun Chen ${ }^{1}$ \\ ${ }^{1}$ School of Highway, Chang'an University, Xi'an 710064, China \\ ${ }^{2}$ Powerchina Roadbridge Group Co., Ltd., Beijing 100048, China \\ Correspondence should be addressed to Jianxun Chen; chenjx1969@chd.edu.cn
}

Received 1 May 2020; Revised 10 July 2020; Accepted 29 July 2020; Published 13 August 2020

Academic Editor: Chunshun Zhang

Copyright (c) 2020 Yanbin Luo et al. This is an open access article distributed under the Creative Commons Attribution License, which permits unrestricted use, distribution, and reproduction in any medium, provided the original work is properly cited.

\begin{abstract}
The number of super-large-span tunnels is increasing in both new construction and reconstruction projects in China recently. In super-large-span tunneling engineering, the deformation properties and mechanical behaviors of tunnel portal structure are more complex than those of common tunnel due to the flatter shape and larger construction span. The mechanical behaviors of rock mass change in response to different sequential excavation methods and supporting parameters. The upper bench CD method has been gradually applied in the construction of super-large-span tunnels in China. In this paper, the design parameters for the supporting structure of super-large-span tunnel were studied by the field monitoring and numerical modeling in a case study of Laohushan tunnel. It was found that the crown settlement was larger than the clearance convergence, and the stress of arch was greater than that of the side wall in tunnel portal section. The invert structure was flat with small curvature. Therefore, the shotcrete was mainly subjected to tensile stress. The use of $\mathrm{H} 200 \times 200$ steel rib with spacing of $60 \mathrm{~cm}$ and C25 shotcrete with thickness of $30 \mathrm{~cm}$ is recommended. The results of this paper provide basis for the development of design specifications and construction standards for super-large-span tunnels and provide reference for similar projects in the future.
\end{abstract}

\section{Introduction}

With the rapid development of national economy and the gradual growth of highway transportation volume, the existing single-hole two-lane tunnels are unable to meet the needs of transportation and travel in the economically developed areas and suburban megacities [1-8]. Considering that the route corridor is nonrenewable, there are more and more single-hole four-lane tunnels in newly built highway and reconstruction projects. However, there is no rich experience in design and construction of super-large-span highway tunnels in China engineering industry. In addition, there is no system standard for the construction of superlarge-span highway tunnels, and the design principle of engineering analogy is still in use in the design of two-lane or three-lane tunnels. There are many kinds of supporting forms of tunnel portal section, for example, primary supporting with two-layer secondary lining, two-layer primary supporting with high-strength secondary lining, and highstrength primary supporting with secondary lining. Moreover, there is no national standard for design parameters and construction methods. Shi et al. proposed a method for determining the minimum burial depth of tunnels by considering reinforcement control measures, and a largespan tunnel with excavation area of $376 \mathrm{~m}^{2}$ was excavated successfully [9-11]. In the research of tunnel supporting parameters, based on geotechnical engineering inversion theory, the reasonable supporting parameters were proposed by comparing the supporting parameters with the optimized supporting parameters in tunnel project [12-15]. A reasonable supporting method of four-lane highway tunnels was proposed by simulating the structural form and 
supporting parameters of super-large-span tunnels [16-19]. A reasonable supporting form for special strata was proposed by combining numerical simulation and on-site monitoring data [20-26]. However, the design parameters of super-large-span tunnel supporting structure were mainly studied for single-supporting parameter in a single-stratum environment through numerical simulation or model test. The applicability of research results could not be widely used.

The New Austrian Tunneling Method is being widely used in China because it is simple, cost-effective, adaptive, and technically feasible [27-31]. Sequential excavation method (SEM) is widely used in super-large-span tunnels, which reflects the design concept of the New Austrian Tunneling Method. Even though great engineering construction achievements were made in terms of the construction of super-large-span tunnels using SEM, there are limited number of related studies on this topic in international journals [32-35]. Gong et al. (2009) studied the settlement of vault and ground surface under different construction methods such as double-sided guide tunnel method, central diaphragm (CD) method, and upper-lower bench method using finite element software based on the large cross section tunnel in Heshang [31]. Jiang et al. established the discrete element numerical analysis model and optimized the construction method of super-long-span tunnel in a case study of Kuiqi No. 2 tunnel project [36]. Gao et al. used finite element software to study the construction of tunnel by using double-sided guide tunnel method, CD method, and cross diaphragm (CRD) method based on Liantang Tunnel [37]. Through field tests, Zhou et al. proposed that the excavations of first heading in the upper bench $o$, the second heading in upper bench, and the core soil are the key points to be controlled in the tunnel construction when the both-side heading method is adopted in a case study of Longtoushan Tunnel [38]. Relying on the Dadongshan Tunnel, Zhang studied the deformation of surrounding rock in the excavation of tunnel grade IV by CRD method and grade V by double-sided pilot pit method, through field monitoring and measurement [27]. Li et al. proposed to study the deformation of surrounding rock and the stress of supporting structure of the tunnel during construction with double-sided guide pit method and CD method through field tests, relying on the No. 1 tunnel project of Qichong Village, Guiyang [39]. From the above research on the construction methods of large-span tunnels, it can be seen that the sectional excavation method has been widely used [40], and the upper bench CD method has been less applicated in the construction of large-span tunnels.

In this paper, based on the Laohushan Tunnel with super-large span of $20.008 \mathrm{~m}$, the mechanical characteristics and supporting parameters of supporting structure near tunnel portal were studied and analyzed through on-site investigation and field test monitoring in the construction process of Laohushan super-large-span tunnel. At the same time, this paper uses the method of numerical simulation to analyze and calculate the primary supporting internal force and material safety factor to verify the safety and applicability of design support parameters in tunnel portal section. This paper provides project analogy method reference for the construction of similar projects in the future, as well as the formulation of specifications and standards for superlarge-span highway tunnels in China.

\section{Project Overview}

This paper takes the Jinan Belt Highway tunnel groups as the supporting project and selects the Laohushan Tunnel as the research object. Laohushan Tunnel is located in Jinan City, Shandong Province, China. The tunnel is designed as two holes with four lanes in single hole. The left line is $1740 \mathrm{~m}$, the right line is $1888 \mathrm{~m}$, and the maximum excavation span is $20.008 \mathrm{~m}$, which belongs to super-large-span highway tunnel. The stratum of tunnel portal section is the paleoweathering crust of the Lower Ordovician $\left(\mathrm{O}_{1}\right)$ of Paleozoic, and the lithology is the paleyellow residual gravel soil and the gravel block soil. The stratum structure is compact, the cementing property is good, and the soil layer is hard, but it is easy to soften when exposed to water. The tunnel location and the landform of tunnel site are shown in Figures 1 and 2, respectively.

2.1. Primary Supporting Structure Parameters. The primary supporting structure parameters $(\mathrm{H} 200 \times 200$ steel rib with spacing of $60 \mathrm{~cm}, \mathrm{C} 25$ shotcrete with thickness of $30 \mathrm{~cm}$ ) were first selected according to the engineering analogy. The composite lining structure is adopted in the supporting form of Laohushan Tunnel and the supporting parameters of tunnel portal section are shown in Figure 3. The support system of tunnel portal is shown in Table 1.

2.2. Construction Approaches. The upper bench CD method was adopted in the construction of tunnel portal as shown in Figure 4.

The construction procedures of upper bench CD method are as follows:

(a) Excavate the upper bench part 1 and timely construct structure II and the upper part of structure I

(b) When part 1 is excavated $15-20 \mathrm{~m}$ ahead of part 2, excavate part 2 of the upper bench and construct the upper part of structure III in time

(c) When part 2 is excavated $20-30 \mathrm{~m}$ ahead of part 3, excavate part 3 of the left and right lower guide pits and construct the lower part of structures I and III in time

(d) Remove temporary support II, excavate part 4, timely construct support structure IV of invert, and fill lower part $\mathrm{V}$ of invert secondary lining

(e) Construct superstructure $\mathrm{V}$ of secondary lining

\section{Numerical Simulation}

Based on the above supporting parameters, the numerical calculation was carried out by MIDAS-GTS to obtain the deformation properties and mechanical behaviors of tunnel structure. In the numerical model, the supporting effect of presupports, systematic bolts, and locking bolts (tube) was simplified as the reinforcement area (the cohesive force and 


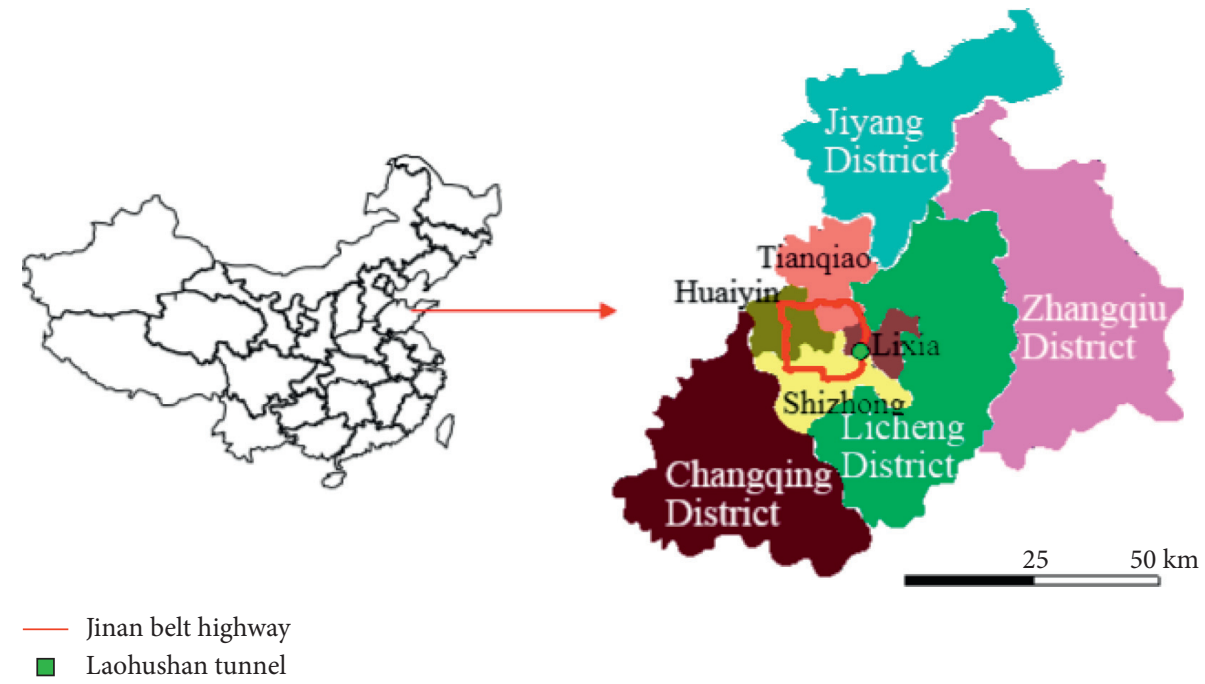

Figure 1: Location of Laohushan tunnel.

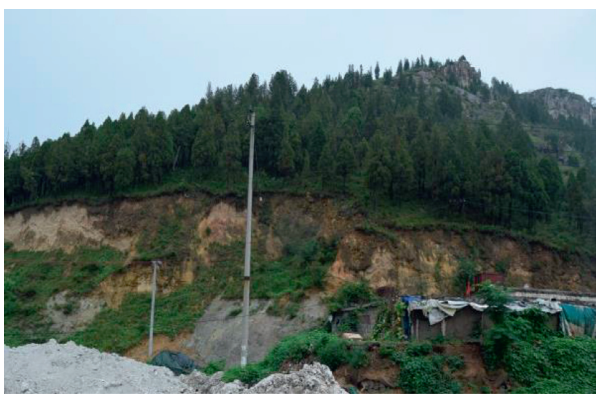

(a)

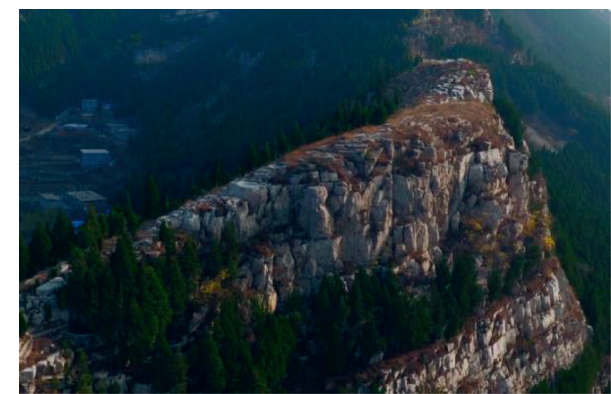

(b)

FIgURE 2: The landform of tunnel site.

friction angle of the original rock were enhanced by $20 \%$ [39]). The primary supporting was simulated as the beam element, and the physical parameters were obtained by the equivalent reduction of steel rib and shotcrete, which was in accordance with the "Unified Theory of CFST" [41]. After the equivalent reduction, the physical parameters were selected as the modeling parameters of primary supporting. In this paper, the comprehensive safety factor method in the "Guidelines for Design of Highway Tunnel" [42] was used to check and evaluate the primary supporting of super-largespan highway tunnel. According to (1) to (4), the total axial force and total moment assumed by the primary supporting are undertaken together by the steel rib and shotcrete:

$$
\begin{aligned}
& N_{h}=N \frac{A_{h} E_{h}}{A_{h} E_{h}+A_{g} E_{g}}, \\
& M_{h}=0, \\
& N_{\mathrm{g}}=N \frac{A_{g} E_{g}}{A_{h} E_{h}+A_{g} E_{g}}, \\
& M_{\mathrm{g}}=M,
\end{aligned}
$$

where $N, M$ are the total axial force and total moment of checking section in unit length $(\mathrm{kN}, \mathrm{kN} \cdot \mathrm{m}) ; A_{h}, A_{g}$ are the area of calculation section of shotcrete and steel rib $\left(\mathrm{m}^{2}\right) ; E_{h}$, $E_{g}$ are the elastic modulus of shotcrete and steel rib $(\mathrm{kPa})$; $N_{h}, N_{g}$ are the axial force of shotcrete and steel rib $(\mathrm{kN})$; and $M_{h}, M_{g}$ are the moment of shotcrete and steel rib $(\mathrm{kN} \cdot \mathrm{m})$.

When the strength of shotcrete and steel rib was checked by the comprehensive safety factor method, it should meet the stipulation of (5) to (6). The formulas are shown as follows:

$$
\begin{aligned}
K_{h y} N_{h} & \leq \alpha R_{h y} A_{h}, \\
K_{g}\left(\frac{N_{g}}{A_{g}}+\frac{M_{g}}{W_{g}}\right) & \leq R_{g y}, \\
K_{g}\left(\frac{N_{g}}{A_{g}}-\frac{M_{g}}{W_{g}}\right) & \leq R_{g l},
\end{aligned}
$$

where $R_{h y}$ is the ultimate compressive strength of steel rib $(\mathrm{kPa}) ; R_{g y}$ is the ultimate compressive strength of steel rib $(\mathrm{kPa}) ; R_{g l}$ is the ultimate tensile strength of steel rib $(\mathrm{kPa})$; $K_{h y}$ is the comprehensive safety factor of compressive strength of shotcrete; $K_{g}$ is the comprehensive safety factor 


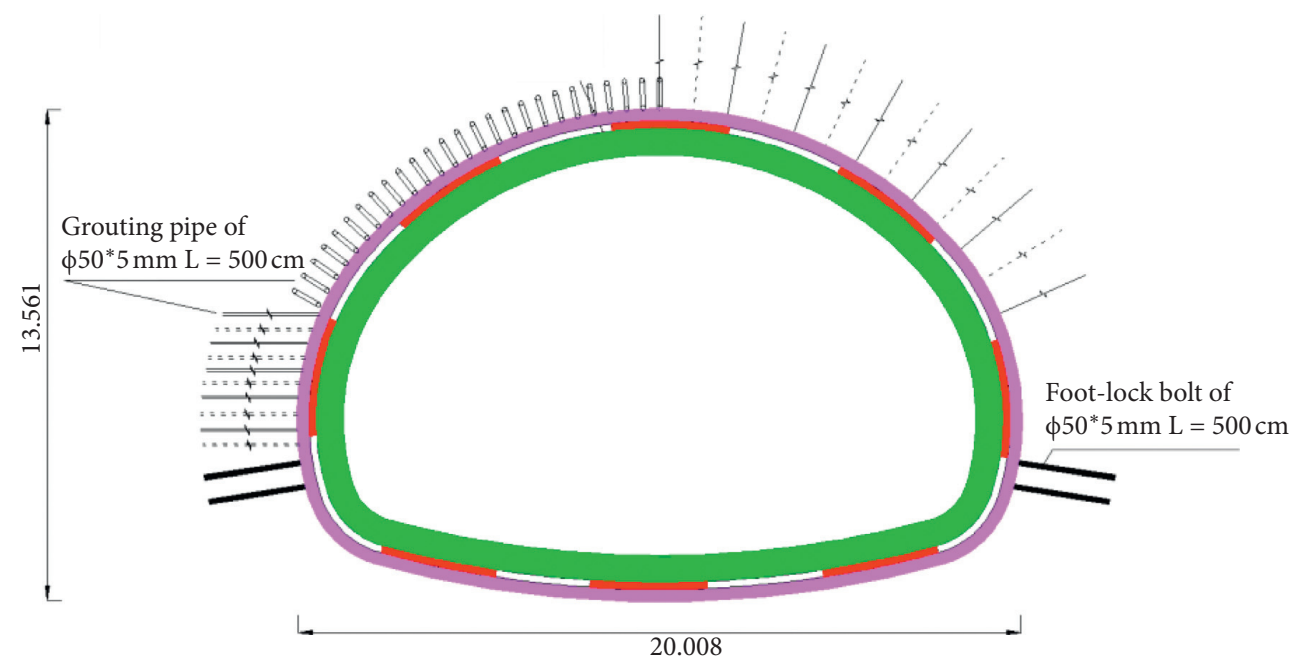

FIGURE 3: Supporting parameters of tunnel portal.

TABLe 1: The support system of the tunnel portal.

\begin{tabular}{lr}
$\begin{array}{l}\text { Temporary } \\
\text { support }\end{array}$ & $\begin{array}{c}\varphi 0 \times 5 \text { pregrouting pipe: first row } L=6 \mathrm{~m} \text {, angle }=6^{\circ} ; \text { second row } L=3 \mathrm{~m} \text {, angle }=15^{\circ} ; \text { circumferential spacing }=40 \mathrm{~cm}, \\
\text { longitudinal spacing }=1.2 \mathrm{~m} .\end{array}$ \\
\hline $\begin{array}{r}\text { Primary support } \\
\text { C25 shotcrete, thickness }=30 \mathrm{~cm} ; \varphi 25 \text { hollow grouting anchor } L=500 \mathrm{~cm} \text {, spacing }=60 \mathrm{~cm} ; \text { double layer } \varphi 8 \text { steel mesh, } \\
\text { spacing }=20 \times 20 \mathrm{~cm} ; \mathrm{H} 200 \text { steel rib, spacing }=60 \mathrm{~cm} \text {; reserved deformation }=20 \mathrm{~cm} .\end{array}$ \\
\hline $\begin{array}{r}\text { Secondary lining } \\
\text { C30 concrete, thickness }=70 \mathrm{~cm} ; 40 \mathrm{~g} / \mathrm{m}^{2} \text { nonwoven fabrics; EVA waterproof cloth, thickness }=1.5 \mathrm{~mm} .\end{array}$ \\
\hline
\end{tabular}

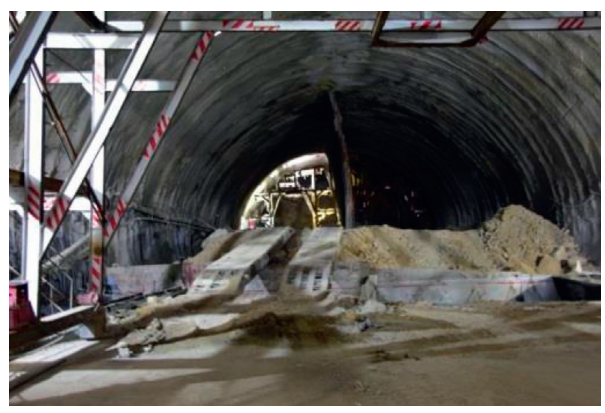

(a)

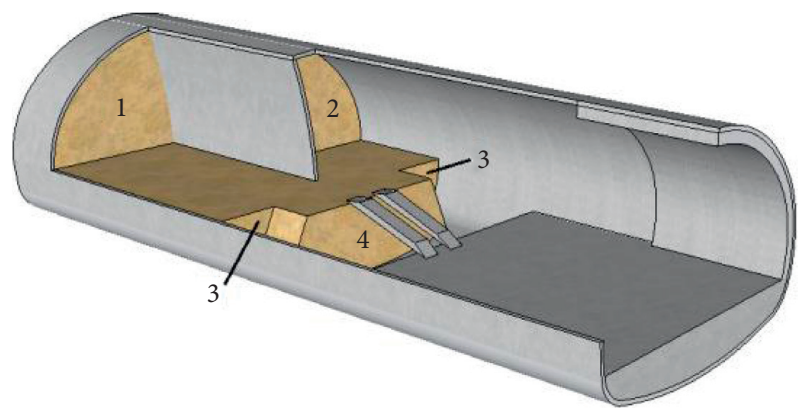

(b)

FIgURE 4: Construction of upper bench CD method. (a) Field construction. (b) Three-dimensional schematic diagram.

of compressive and tensile strength of steel rib; $W_{g}$ is the bending strength of steel rib checking section $\left(\mathrm{m}^{3}\right)$; and $\alpha$ is the eccentric influence coefficient.

The excavation section width of the model was $20 \mathrm{~m}$, and the upper distance of the tunnel portal model took the actual rock mass height. The horizontal distance of the model took 3 times the tunnel diameter $(20 \mathrm{~m})$, the horizontal direction constraint was applied to the left and right sides of model, and the vertical direction constraint was applied to the bottom boundary of model. The initial ground stress only considered the effect of self-heavy stress. Rock mass was considered an ideal elastic material, subjected to the Mohr-Coulomb yield criterion. The lining structure adopted an elastic model, and the lining structure adopted a beam unit. The physical and mechanical parameters of rock mass used in the modeling are shown in Table 2, and the finite element model is shown in Figure 5.

The simulated deformation results of tunnel portal section are shown in Figure 6. The simulated crown settlement value is $19.7 \mathrm{~mm}$, and the horizontal convergence is $7.8 \mathrm{~mm}$. The overall deformation of structure is small, far less than the ultimate displacement value of $200 \mathrm{~mm}$.

The 12 monitoring points were selected to analyze the structural stress and safety factor. The structure was calculated according to the method of internal force and safety factor in the "Design Rules for Highway Tunnels" [42]. The results were shown in Table 3 .

The arch stress of primary supporting was slightly larger than that of side wall and invert. The maximum axial force $(2472 \mathrm{kN})$ of shotcrete appears at $60^{\circ}$ left of center of arch, and 
TABLE 2: The physical and mechanical parameters of the rock mass.

\begin{tabular}{lccccc}
\hline Rock mass & $\begin{array}{c}\text { Deformation modulus, E } \\
(\mathrm{GPa})\end{array}$ & $\begin{array}{c}\text { Poisson ratio, } \\
\mu\end{array}$ & $\begin{array}{c}\text { Internal friction angle, } \\
\varphi\left({ }^{\circ}\right)\end{array}$ & $\begin{array}{c}\text { Cohesion, C } \\
(\mathrm{MPa})\end{array}$ & $\begin{array}{c}\text { Volume weight }\left(\mathrm{kN} / \mathrm{m}^{3}\right) \\
\text { V2 }\end{array}$ \\
V2 reinforced area & 3 & 0.35 & 23 & 0.66 & 18 \\
\hline
\end{tabular}

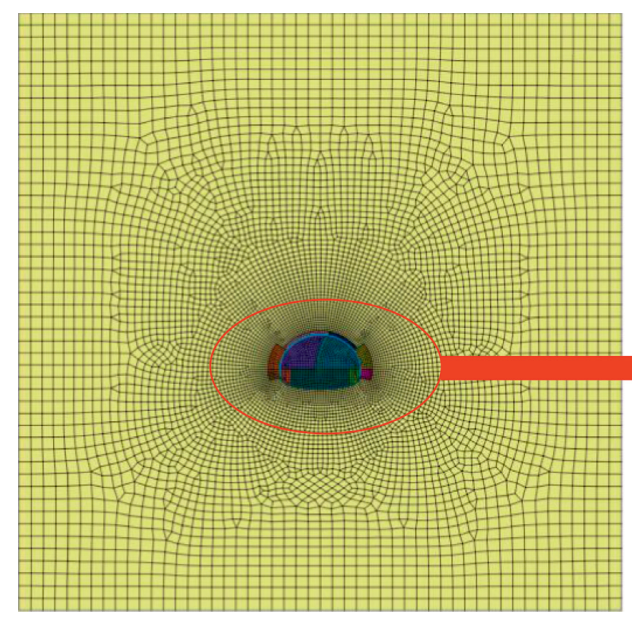

(a)

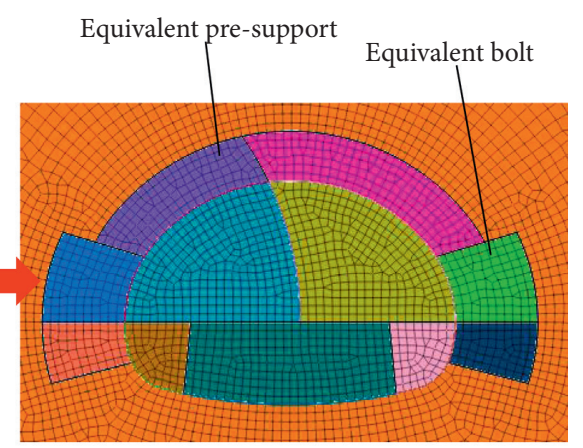

(b)

Figure 5: Primary supporting model of sections near tunnel portal. (a) Overall model. (b) Partial model.

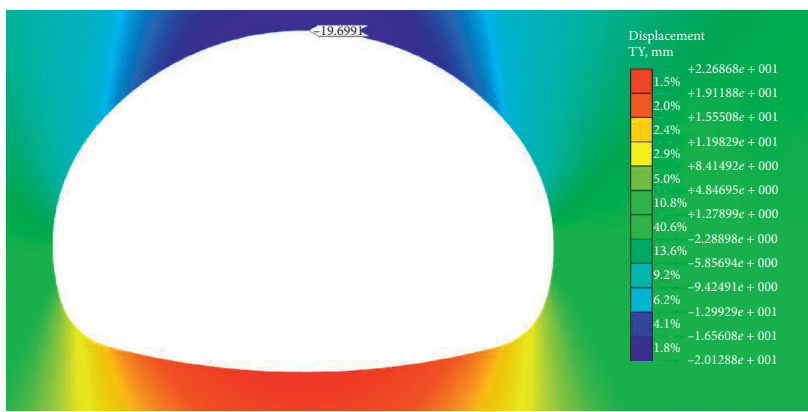

(a)

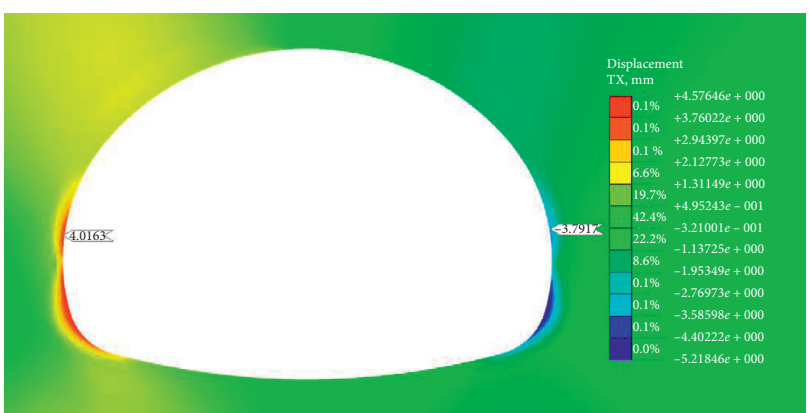

(b)

FIGURE 6: Simulated results of tunnel portal section. (a) Crown settlement. (b) Horizontal convergence.

the safety factor was 2.7. The maximum bending moment $(-8.2 \mathrm{kN} \mathrm{m})$ of steel rib appeared on the right arch foot and side wall, with safety factor of 4.2. According to the "Design Rules for Highway Tunnels" [38], the safety factors of steel rib and shotcrete under the basic variable combination of QZH-II were 2.0 (compression/tensile), 3.6 (tensile), and 2.4 (compression/ tensile). The safety factor of the primary support structure of tunnel portal section was larger than the specified value. It showed that the design parameters could meet the structural safety. The results indicated that the secondary lining was less stressed and could be used as safety stock.

\section{Field Monitoring}

4.1. Monitoring Scheme. Test sections were selected to conduct deformation and stress monitoring near tunnel portal section based on the engineering geological conditions and the construction characteristics of Laohushan Tunnel. Monitoring tunnel deformation is an important method to obtain the deformation law of tunnel, and it could further guide the construction [26]. Shen (2014) conducted extensometers and stressmeters to measure the deformation and the stress change in the rock mass based on mine tunnel road [43]. The three deformation monitoring sections were selected in $\mathrm{YK} 2+125, \mathrm{YK} 2+133$, and YK2 + 140, among which YK2 +133 was also the stress monitoring section. The monitoring sections were shown in Table 4 and Figure 7. The layouts of deformation and stress monitoring points are shown in Figure 8. The stress monitoring points are named as follows: "element + layout number + position number". The positive value means compression, and the negative value means tension. 
TABle 3: Primary supporting internal force and material safety factor.

\begin{tabular}{|c|c|c|c|c|c|c|c|}
\hline Number & Position & $\begin{array}{l}\text { Shotcrete axial } \\
\text { force }(\mathrm{kN})\end{array}$ & $\begin{array}{c}\text { Steel rib } \\
\text { axial force }(\mathrm{kN})\end{array}$ & $\begin{array}{c}\text { Steel rib } \\
\text { moment } \\
(\mathrm{kN} \cdot \mathrm{m})\end{array}$ & $\begin{array}{l}\text { Safety factor of } \\
\text { concrete }\end{array}$ & $\begin{array}{c}\text { Tensile safety } \\
\text { factor of steel rib }\end{array}$ & $\begin{array}{l}\text { Compressive safety } \\
\text { factor of steel rib }\end{array}$ \\
\hline 0 & Arch & 1087 & 206 & -1 & 6.2 (compression) & 12.8 & 8.8 \\
\hline 1 & $\begin{array}{c}30^{\circ} \text { left of } \\
\text { center of arch }\end{array}$ & 1780 & 331 & -0.1 & 3.8 (compression) & - & 6.4 \\
\hline 2 & $\begin{array}{l}30^{\circ} \text { right of } \\
\text { center of arch }\end{array}$ & 1617 & 290 & 0.7 & 4.2 (compression) & 6.8 & 8.2 \\
\hline 3 & $\begin{array}{c}60^{\circ} \text { left of } \\
\text { center of arch }\end{array}$ & 2472 & 479 & -1.5 & 2.7 (compression) & 5.1 & 4.3 \\
\hline 4 & $\begin{array}{l}60^{\circ} \text { right of } \\
\text { center of arch }\end{array}$ & 2306 & 430 & 0 & 2.9 (compression) & 5 & 5 \\
\hline 5 & Left arch foot & 1855 & 366 & -2.6 & 3.7 (compression) & 8.2 & 4.6 \\
\hline 6 & $\begin{array}{l}\text { Right arch } \\
\text { foot }\end{array}$ & 1111 & 178 & -8.2 & 4.9 (tensile) & - & 4.2 \\
\hline 7 & Left side wall & 647 & 147 & -5.3 & 8.9 (compression) & - & 6 \\
\hline 8 & $\begin{array}{l}\text { Right side } \\
\text { wall }\end{array}$ & 585 & 178 & -8.2 & 4.1 (compression) & 14.2 & 4.2 \\
\hline 9 & Left invert & 241 & 47 & -0.2 & $\begin{array}{c}28.1 \\
\text { (compression) }\end{array}$ & - & 38 \\
\hline 10 & Right invert & 235 & 47 & -0.5 & $\begin{array}{c}28.8 \\
\text { (compression) }\end{array}$ & - & 32.4 \\
\hline 11 & Invert & 104 & 18 & 0.4 & $\begin{array}{c}63.3 \\
\text { (compression) }\end{array}$ & - & 53.2 \\
\hline
\end{tabular}

TABLE 4: Field monitoring sections.

\begin{tabular}{|c|c|c|c|c|c|c|c|}
\hline Lining type & $\begin{array}{l}\text { Construction } \\
\text { method }\end{array}$ & $\begin{array}{c}\text { Stress } \\
\text { monitoring } \\
\text { section }\end{array}$ & $\begin{array}{c}\text { Deformation } \\
\text { monitoring section }\end{array}$ & $\begin{array}{c}\text { Burial } \\
\text { depth }(\mathrm{m})\end{array}$ & $\begin{array}{c}\text { Clear } \\
\text { distance }(\mathrm{m})\end{array}$ & Lithology & $\begin{array}{l}\text { Number of } \\
\text { buried } \\
\text { elements }\end{array}$ \\
\hline $\begin{array}{l}\text { Shallow burial with } \\
\text { grade V in tunnel } \\
\text { portal }\end{array}$ & $\begin{array}{l}\text { Upper bench CD } \\
\text { method }\end{array}$ & $\mathrm{YK} 2+133$ & $\begin{array}{l}\text { YK2 + } 125 \\
\text { YK2 + } 133 \\
\text { YK2 + 140 }\end{array}$ & 48 & 13.5 & $\begin{array}{l}\text { Residual } \\
\text { soil }\end{array}$ & 120 \\
\hline
\end{tabular}

\subsection{Deformation Properties}

4.2.1. Horizontal Convergence. As can be seen from Figure 9 , the average value of convergence was $11 \mathrm{~mm}$. After the inverted arch construction, the final convergence rate was less than $0.1 \mathrm{~mm} / \mathrm{d}$. The trend of the convergence of arch and the waist portion of wall was basically consistent with time. The stress of rock mass was gradually released after the excavation of first pilot tunnel. The convergence of first pilot tunnel increased rapidly with time, and the stress release of rock mass after the second pilot tunnel excavation was small. The convergence of tunnel increased slowly and tended to stabilize 50 days later. The lower tunnel excavation and the removal of the temporary support had little effect on the tunnel convergence, which indicated that the primary support structure can effectively restrain the deformation of rock mass and the supporting structure was safe and reliable.

Compared with the numerical simulation results, the field monitoring displacement value $(11 \mathrm{~mm})$ is slightly smaller than the simulated value $(13.3 \mathrm{~mm})$. The field monitoring points were laid out at the same time during the primary support construction. Therefore, the measured deformation value loss is small, and it is closer to the displacement value.

4.2.2. Crown Settlement. As shown in Figure 10, the maximum crown settlement (points 1 and 5) is $19.7 \mathrm{~mm}$, and the maximum settlement at the arch waist (points 2 and 6) is $15 \mathrm{~mm}$. After the inverted arch construction, the maximum settlement value and the final settlement value of crown and arch waist are basically the same, and the final settlement rate of arch is less than or equal to $0.1 \mathrm{~mm} / \mathrm{d}$. It can be seen from Figure 10 that the variation of settlement over time in the arch after tunnel excavation is basically the same. Because the stratum was residual soil with high degree of cementation, the settlement of arch increased slowly in the initial stage of excavation. The settlement began to stabilize 20 days later. The lower tunnel excavation, the temporary support removal, the inverted arch construction are all applied after the temporal curve tends to be stable, and the application of these processes has no significant influence on the temporal curve of settlement. Due to the influence of blasting vibration and other factors during the construction process, the data showed 


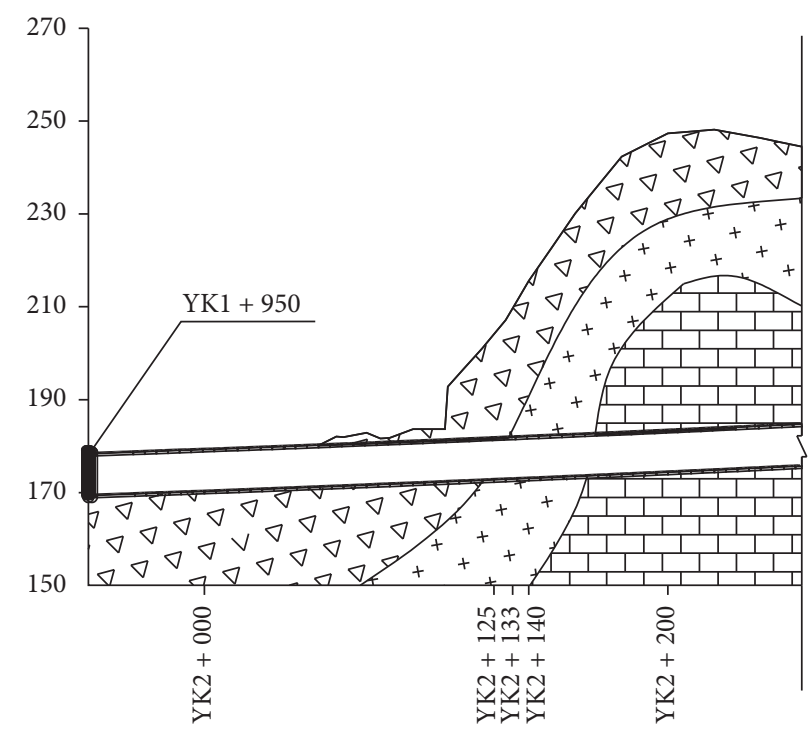

Org Gravelly soil

$++_{+}^{++}$Strongly weathered limestone

臣至 Moderately weathered limestone

FIgURE 7: Monitoring sections in tunnel portal.

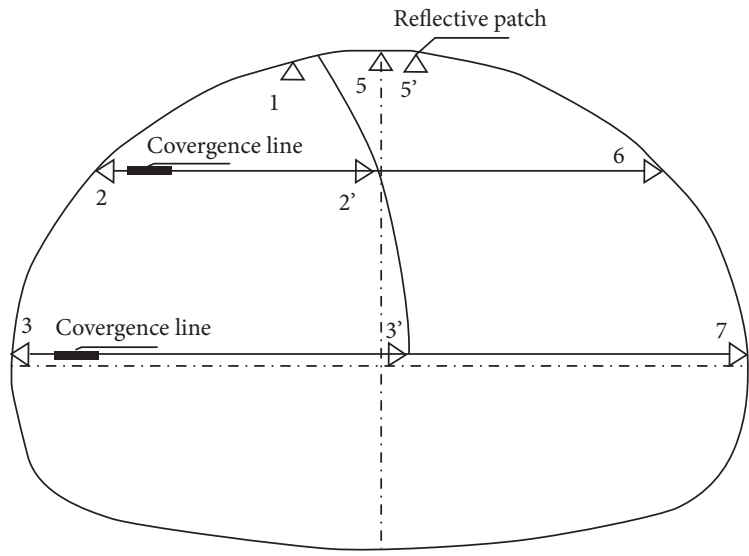

(a)

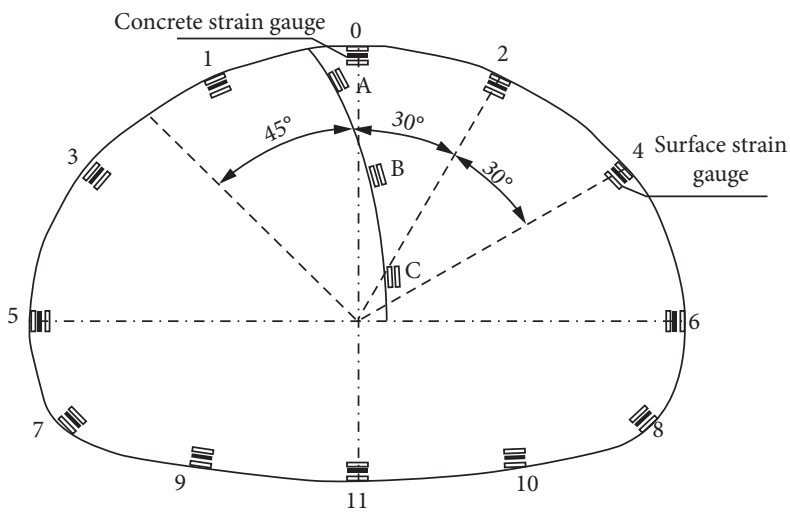

(b)

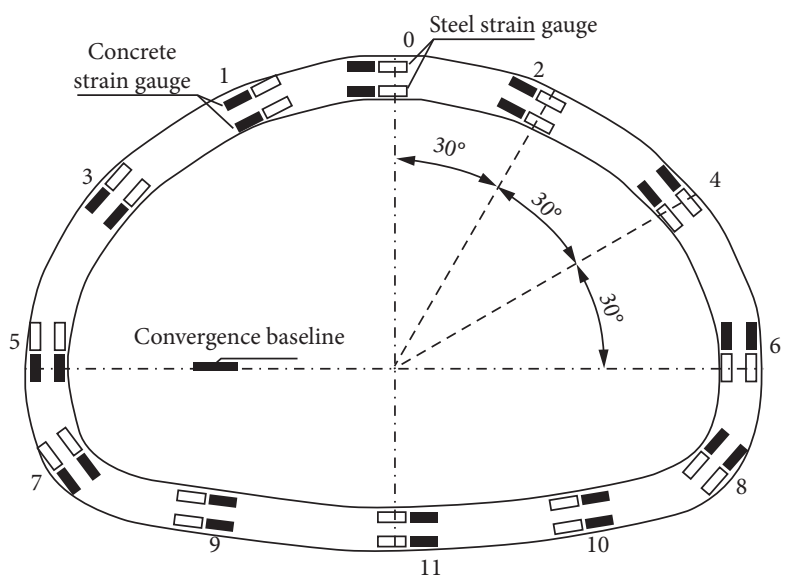

(c)

Figure 8: Layout of monitoring points in tunnel portal section. (a) Layout of deformation monitoring points. (b) Layout of stress monitoring points. (c) Layout of stress test points at secondary lining. 


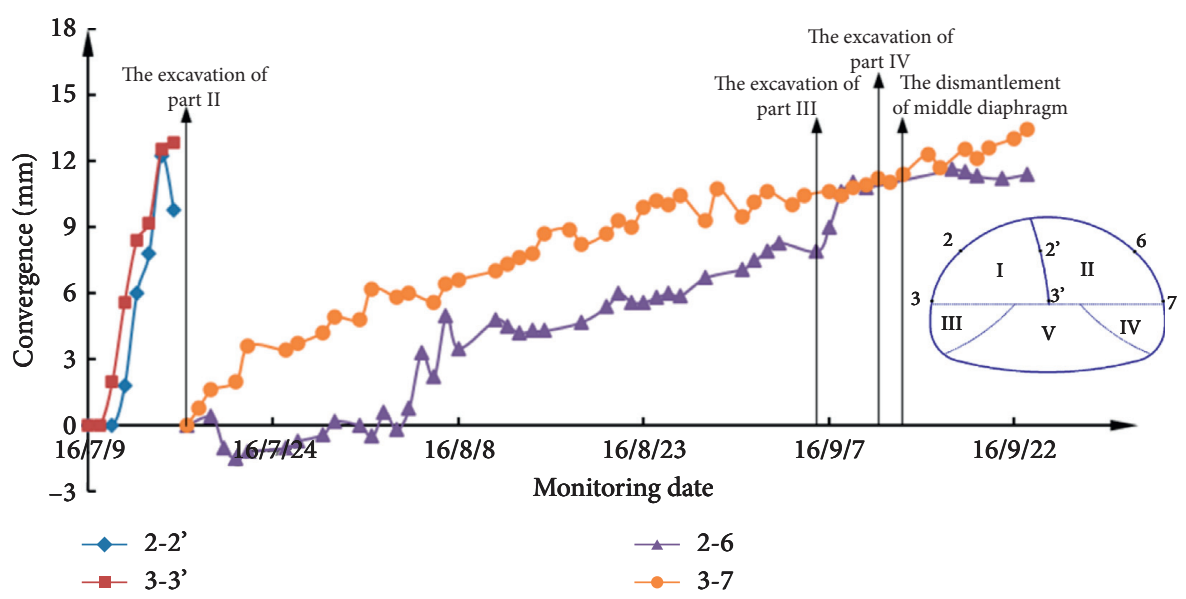

FIgURE 9: Temporal diagram of horizontal convergence.

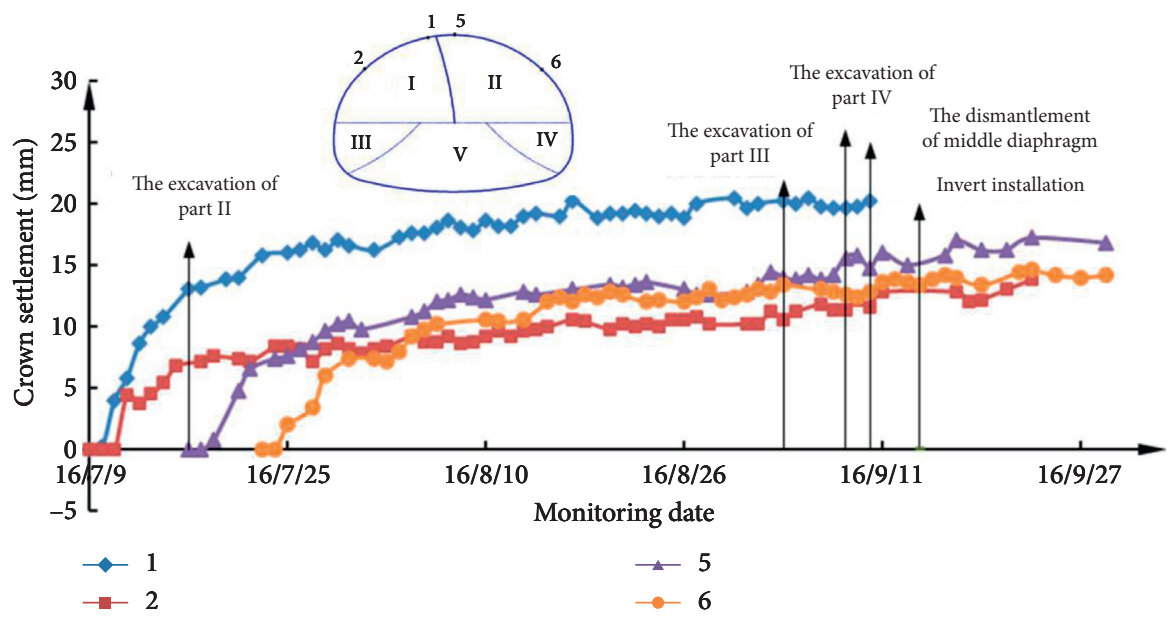

Figure 10: Temporal diagram of crown settlement.

slight jitter, but the overall remained stable. This shows that the primary supporting structure can effectively restrain the deformation of rock mass, and the supporting structure is safe and reliable.

\subsection{Mechanical Characteristics}

4.3.1. Shotcrete Stress. The monitoring stress distribution of shotcrete is shown in Figure 11, and the stress temporal curves are shown in Figure 12.

As shown in Figures 11 and 12, the stress distribution of shotcrete in the test section was uneven, and the shotcrete was mainly subjected to tension. This phenomenon was related to the tunnel section form, indicating that the tunnel flat ratio needs to be optimized.

The maximum compressive stress was $1.98 \mathrm{MPa}$ appearing at the bottom of the invert (point 11), which met the requirements of the ultimate compressive strength of shotcrete. The maximum tensile stress $(2.61 \mathrm{MPa})$ occurred at the right arch wall (point 7), followed by the right arch (point 4) $2.44 \mathrm{MPa}$, which was greater than the tensile strength (1.3 MPa) of C25 shotcrete. However, according to on-site observation, there was no cracking in the shotcrete and the lining structure can be considered safe.

In primary stage, shotcrete is mainly squeezed and then develops into tension state. The stress increased rapidly after the shotcrete was constructed, and the structural stress tended to be stable about 30 days after the secondary lining was completed. The excavation of lower pilot tunnel and the removal of the temporary supporting structure did not have obvious influence on the overall structure. After a shortterm increase in the stress of the shotcrete of most parts of the primary supporting, it tended to stabilize slowly after the secondary lining was applied, except that the shotcrete at the invert arch decreased slowly. This phenomenon was related to the hydration heat of the secondary lining concrete consolidation.

4.3.2. Steel Rib Stress. The stress distribution of steel rib is shown in Figure 13 and the stress temporal curves are shown in Figures 14-16. 


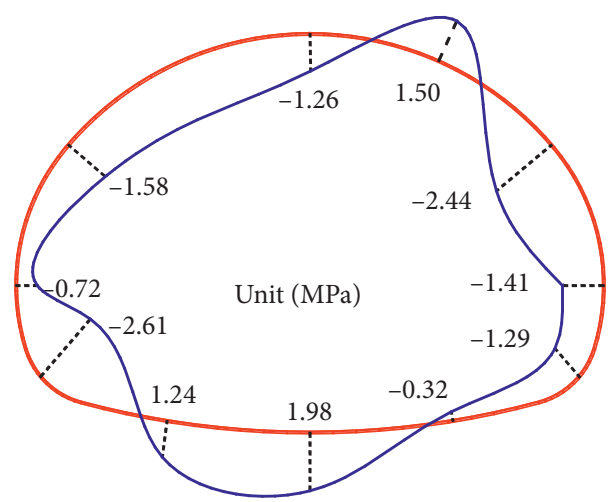

Figure 11: Maximum stress distribution of shotcrete at YK2 + 133 section.

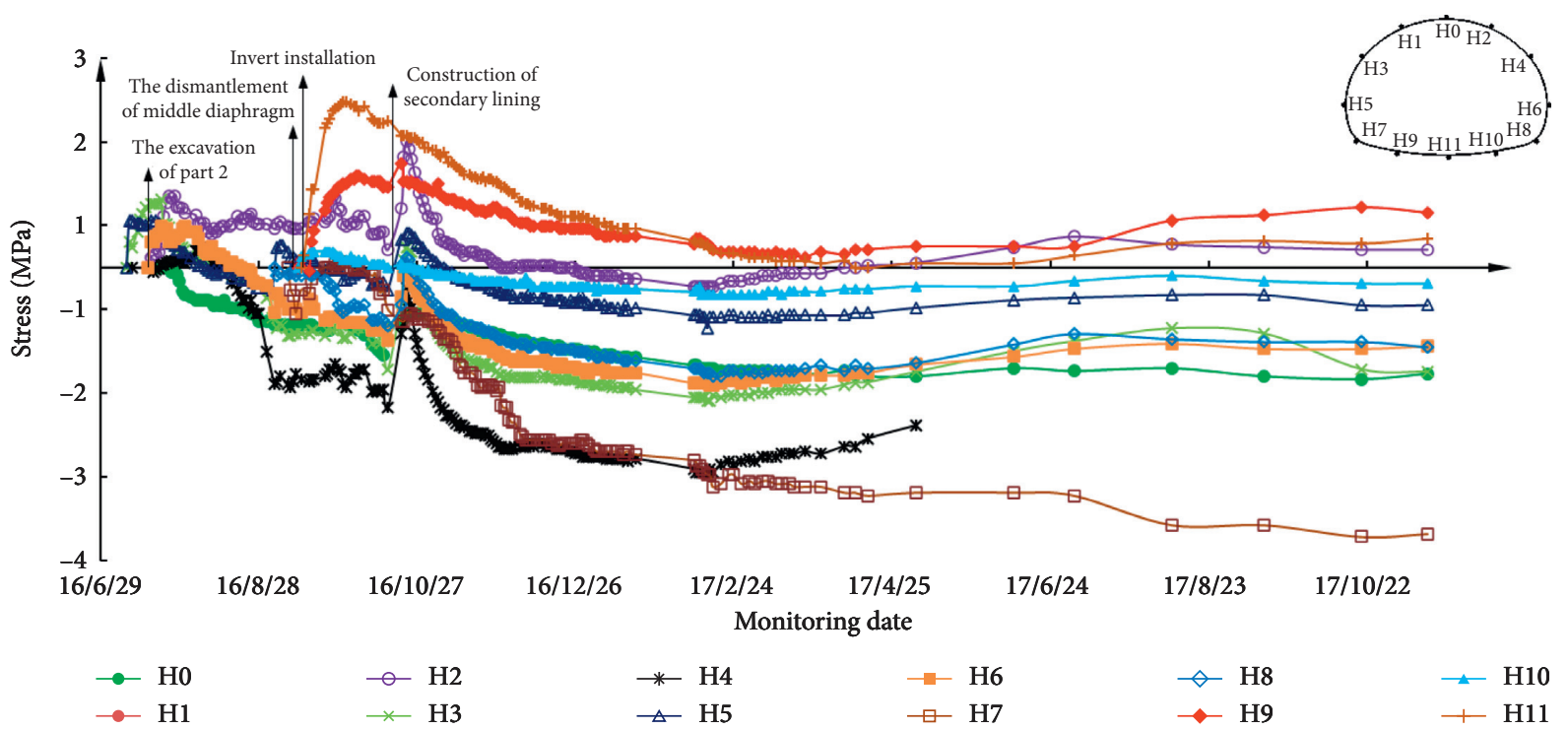

Figure 12: Stress temporal curve of shotcrete at YK2 + 133 section.

Note. A is the first pilot tunnel excavation; B is the second pilot tunnel excavation; $\mathrm{C}$ is the lower tunnel excavation; D is the removed temporary support; $\mathrm{E}$ is the inverted arch construction; $\mathrm{F}$ is the secondary lining construction.

Figures 14-16 show that the stress distribution of steel rib in the test section was uneven, and the stress distribution of stabilized steel rib was consistent with the maximum stress distribution. The steel rib was mainly subjected to compressive stress, and the force of right steel rib was slightly larger than the left side. The maximum compressive stress of the outside of steel rib was $85 \mathrm{MPa}$ appearing at the arch (point 0 ), which accounted for about $23 \%$ of the ultimate yield strength of steel $(375 \mathrm{MPa})$. The maximum compressive stress of the inside of steel rib was $67 \mathrm{MPa}$ appearing at the right side of hance (point 3), which accounted for about $18 \%$ of the ultimate yield strength of steel. The overall stress of steel rib is small and the structure is safe and reliable.

The stress of the temporary supporting was mainly compressive stress, and the inside of arch foot was mainly subjected to tensile stress. The maximum compressive stress was $160 \mathrm{MPa}$ appearing at the arch (point A), which accounted for about $43 \%$ of the ultimate yield strength of steel. The maximum tensile stress was $273 \mathrm{MPa}$ appearing at the bottom (point C), which accounted for about $73 \%$ of the ultimate yield strength. The stress of temporary supporting was relatively large. After the excavation of rear pilot tunnel, the stress of steel rib is abruptly affected by the blasting vibration. Slight yield of temporary supporting steel rib and concrete spalling could be observed in the construction site. With the excavation of rear pilot tunnel, there was no obvious change of steel rib stress. It can be considered that the temporary supporting steel rib structure is safe and can meet the structural safety requirements.

The stress of the inside and outside of primary supporting steel rib was basically consistent with time. After the construction of primary supporting, the stress of steel rib was rapidly increased and tended to be stable after a week. Due to the construction of lower pilot tunnel, the large free face of arch foot on both sides caused a sudden change in the stress of the steel rib of arch foot, and the stress restored 


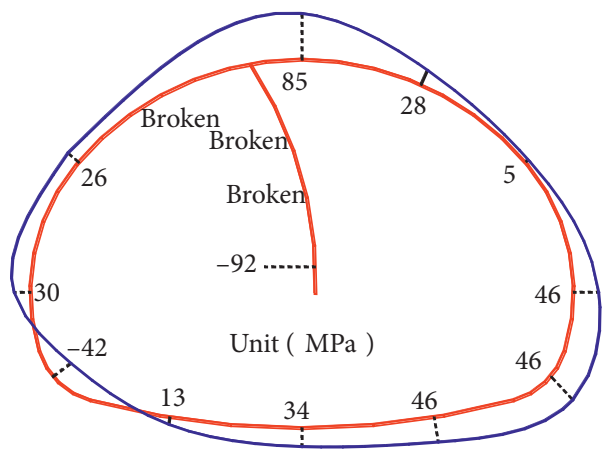

(a)

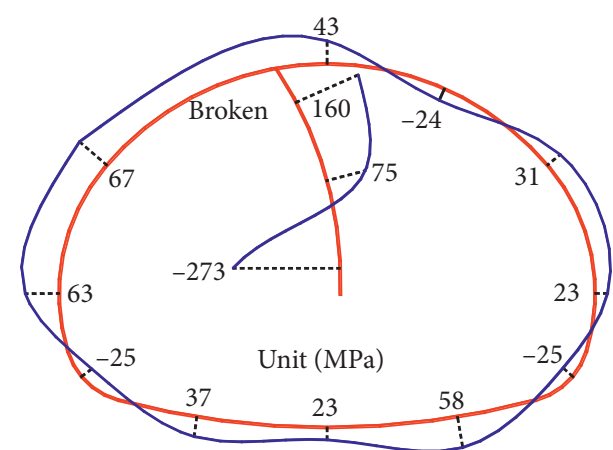

(b)

FIGURE 13: Stress distribution of steel rib in YK2 + 133 section. (a) Maximum value of outside steel rib. (b) Stability value of inside of stress rib.

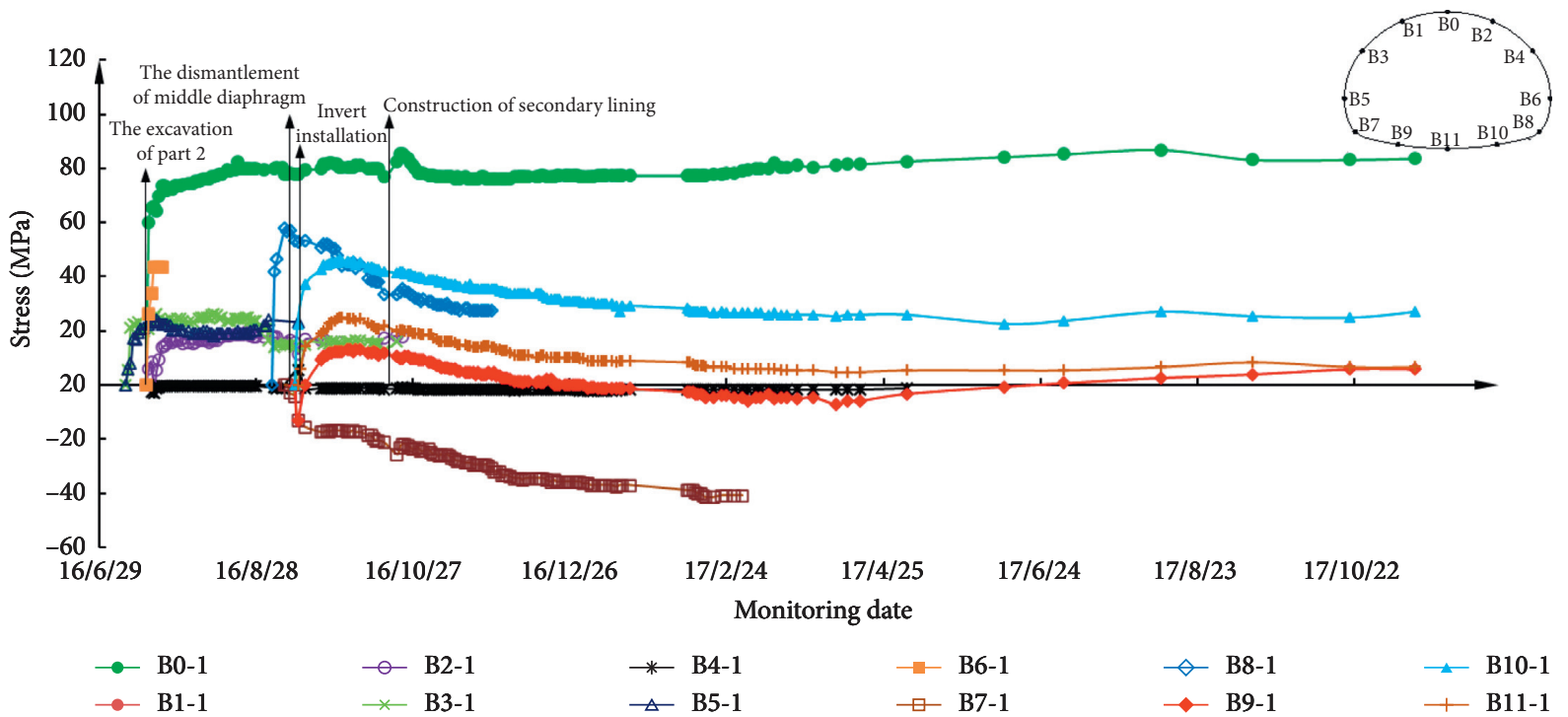

FIGURE 14: The outside stress curves of steel rib in YK2 + 133 section.

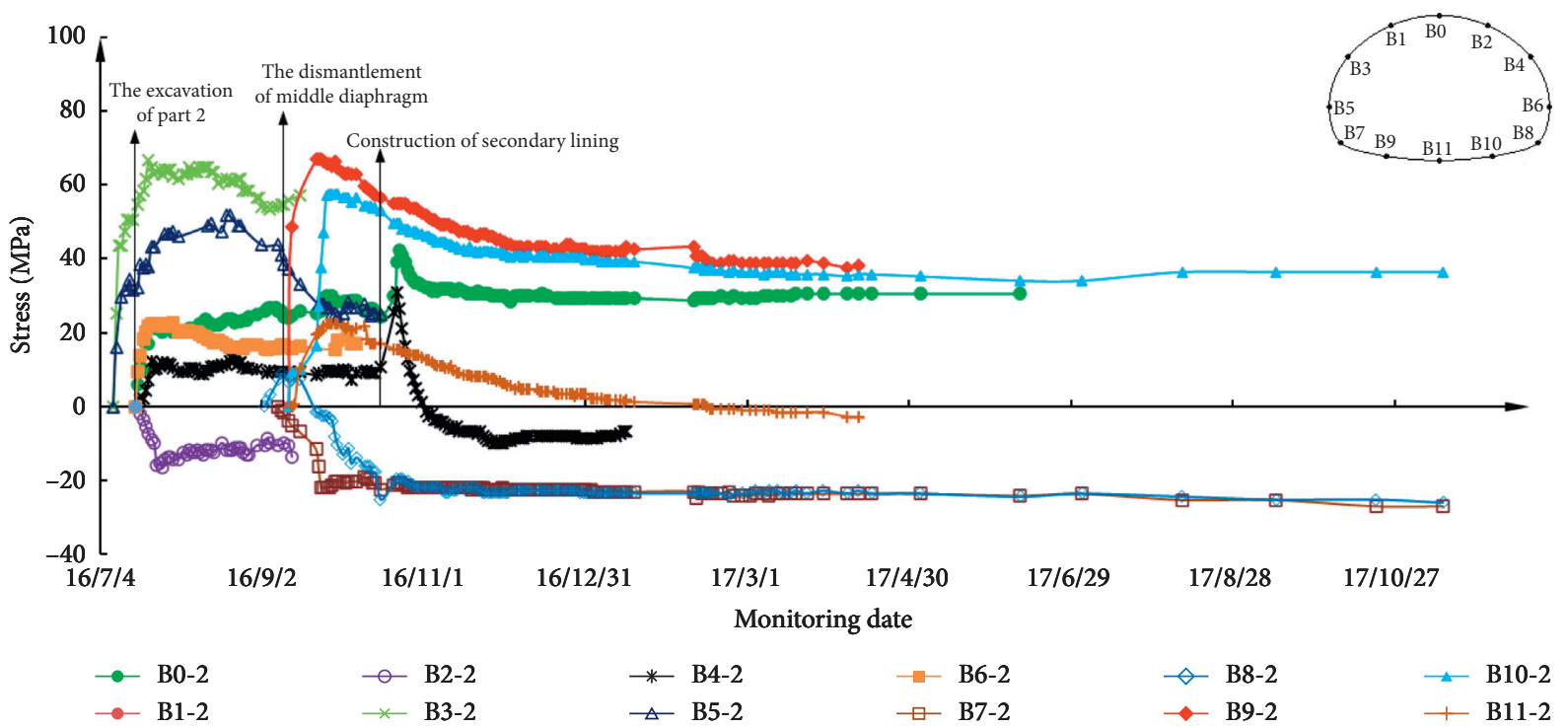

FIgURE 15: The inside stress curves of steel rib in YK2 + 133 section. 


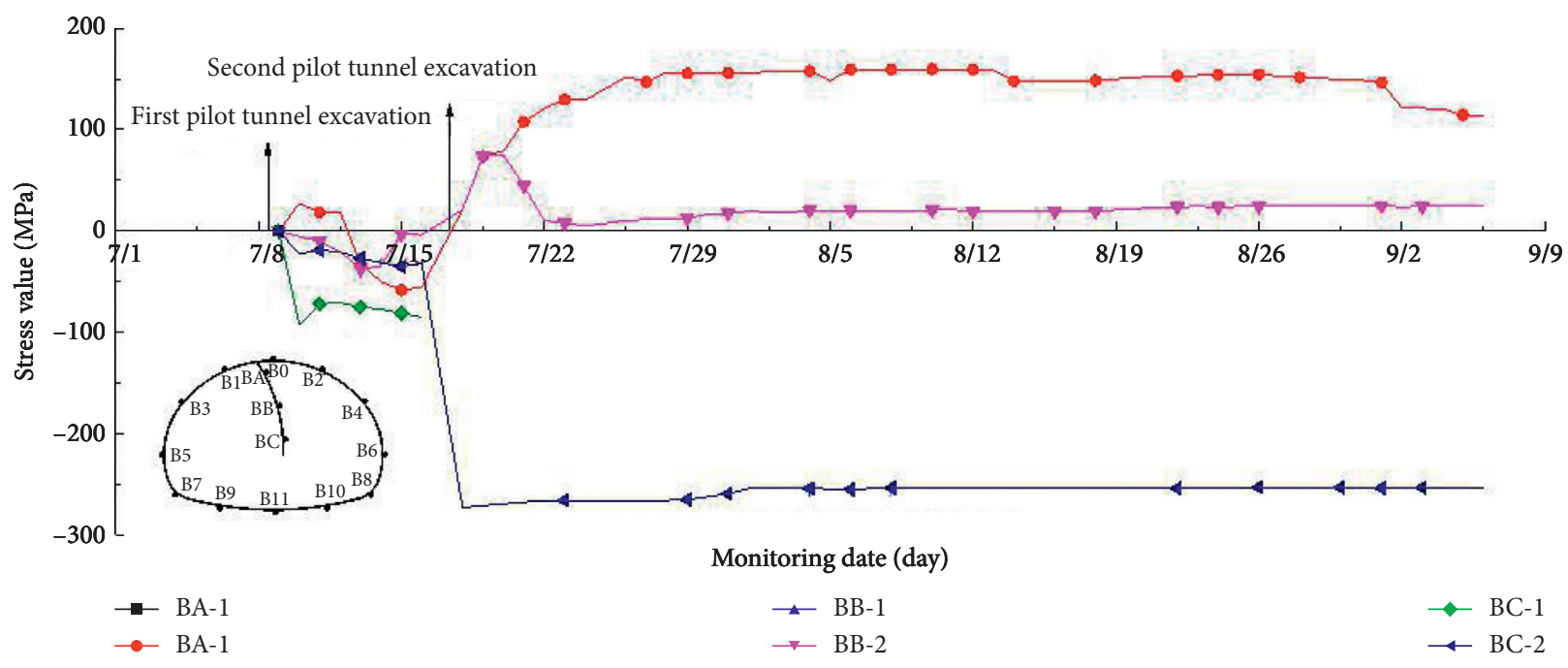

Figure 16: Stress time curve of temporary support steel rib in YK2 + 133 section.

stability after the construction of side wall. The strength of arch steel rib increased in a short period of time and then slowly decreased because of the effect of the self-weight and hardening heat of secondary lining. The primary supporting tended to be stable about 20 days after the completion of secondary lining.

4.3.3. Secondary Lining Steel Stress. The stress distribution of secondary lining steel is shown in Figure 17, and the stress temporal curves are shown in Figures 18 and 19.

As can be seen in Figures 17-19, the secondary lining steel was mainly subjected to compression. After stabilization, the partial position of the invert and the side wall was in tension state. The stress of the internal steel of secondary lining was slightly larger than that of the outer steel. The stress on the right side wall (outside stress) and the invert was slightly larger than that of the arch. The maximum compressive stress occurred on the left side wall (point 7), and the value was $44 \mathrm{MPa}$, which accounted for about $11 \%$ of the steel yield strength. The steel stress on the right side (inside stress) of the secondary lining was slightly larger than that of the left side. The maximum compressive stress value occurred on the right side of the invert (point 9), and the value was $54 \mathrm{MPa}$, which accounted for about $14 \%$ of the steel yield strength. The maximum tensile stress value (46 MPa) appeared on the left side wall (point 7), which accounted for about $12 \%$ of the steel yield strength. This indicated that the secondary lining steel worked well and had sufficient safety reserve.

The change law of the inside and outside steel of secondary lining was consistent. The stress of steel in the invert had a tendency to transition from compression to tension after the invert construction of secondary lining. The overall stress of secondary lining steel changed slowly and tended to be stable about 30 days after the construction of secondary lining.

4.3.4. Concrete Stress of Secondary Lining. The stress distribution of secondary lining concrete is shown in Figure 20, and the stress temporal curves are shown in Figures 21 and 22.
According to Figures 20-22, the inside and outside stress of secondary lining concrete were basically similar. The arch crown and the invert were in tension state, and the rest were subjected to compression. The inside stress of the secondary lining concrete was slightly larger than the outside one. Especially for the invert, the tensile stress was large, and tensile stress occurred at the arch but the value is small. It could be considered that the phenomenon was caused by the small flat ratio of superlarge-span tunnel, the small curvature of invert, and shallow excavation depth, as well as the self-weight of concrete.

The maximum tensile stress $(1.64 \mathrm{MPa})$ of the outside of secondary lining concrete occurred at the invert (point 9, point 11), which was less than the standard tensile value of $\mathrm{C} 30$ concrete of $2.01 \mathrm{MPa}$. The maximum compressive stress $(2.30 \mathrm{MPa})$ occurred in the right side of hance (Point 4$)$, which only accounted for about $12 \%$ of the compressive strength standard value of C30 concrete. The maximum tensile stress (3.22 MPa) of secondary lining concrete (internal) occurred at the right side of invert (point 10), which was greater than the standard tensile value of C30 concrete of 2.01 MPa. However, there was no obvious on-site concrete cracking phenomenon. It is considered that the structure is safe and reliable, and the maximum compressive stress (2.12 $\mathrm{MPa}$ ) occurred at the right arch foot (point 4).

The stress of inside and outside secondary lining concrete was basically consistent. After the construction of secondary lining, the stress in the invert began to increase rapidly. With the consolidation of concrete, the stress decreased gradually, and there was a transition tendency from compression to tension. The tensile of invert gradually increased, and the compression of the remaining parts increased slowly. The stress of secondary lining changed slowly and tended to be stable 30 days later.

4.4. Comparison between Simulation and Field Monitoring. In the simulation hypothesis, the physical and mechanical parameters were assumed to be homogeneous in the rock 


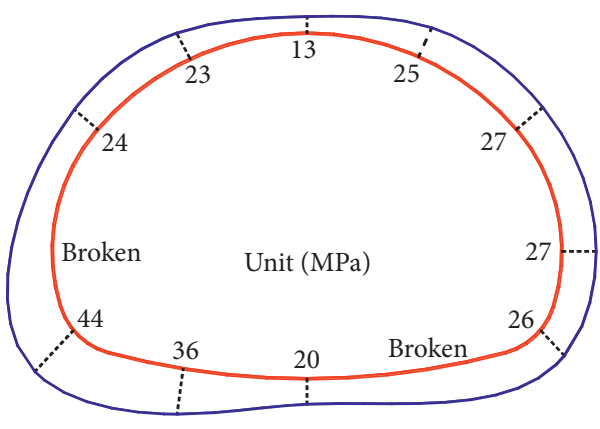

(a)

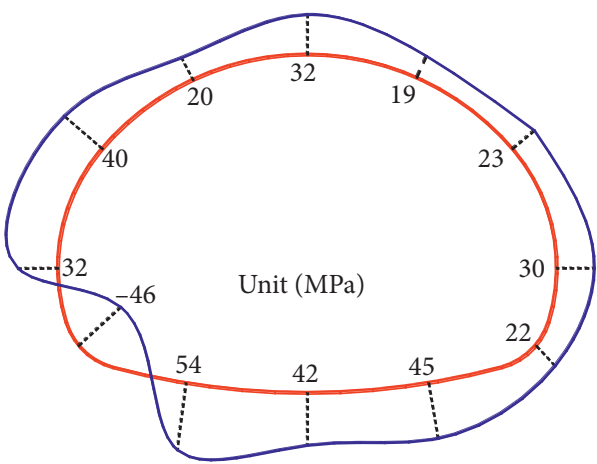

(b)

FIGURE 17: Steel stress distribution of secondary lining in YK2 + 133 section. (a) Maximum stress value of outside stress. (b) Stability value of inside stress.

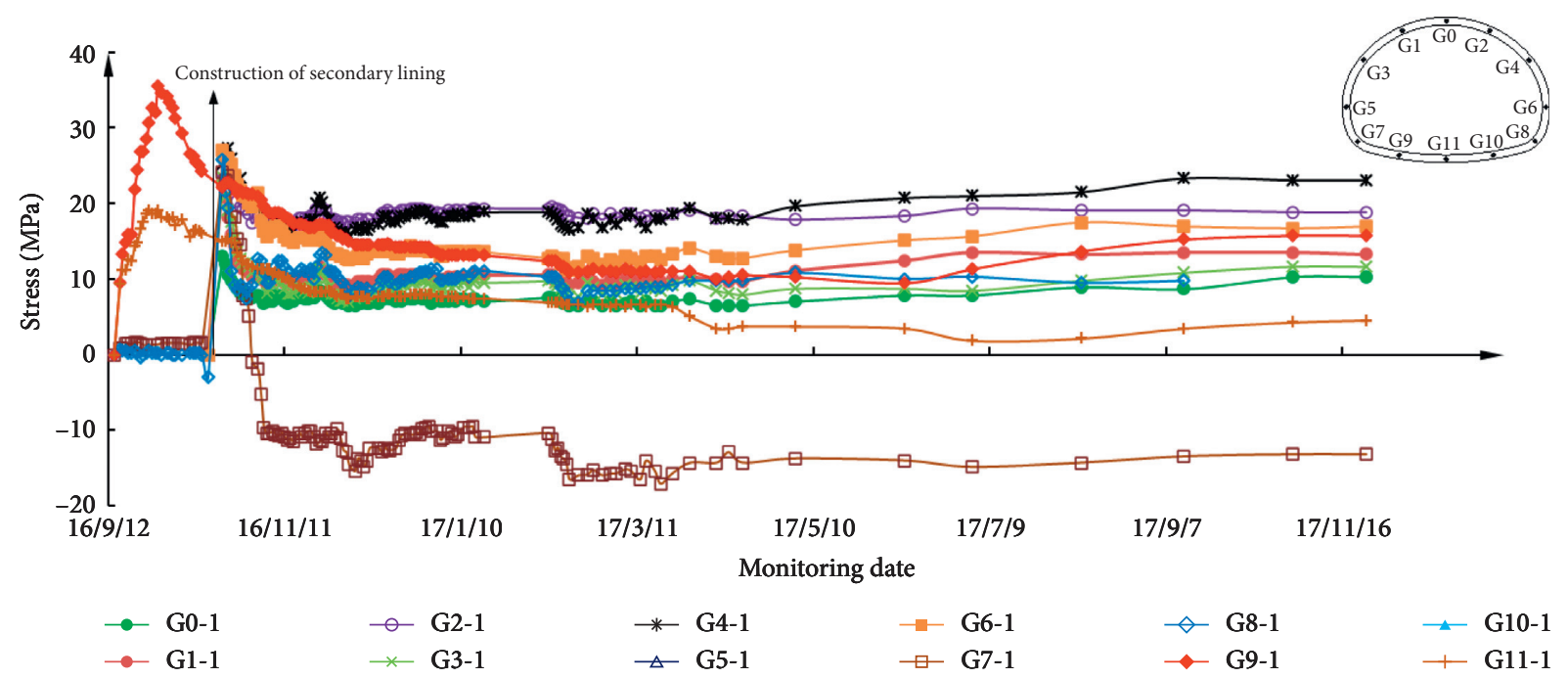

FIgURE 18: Steel stress (outside) time curve of secondary lining in YK2 + 133 section.

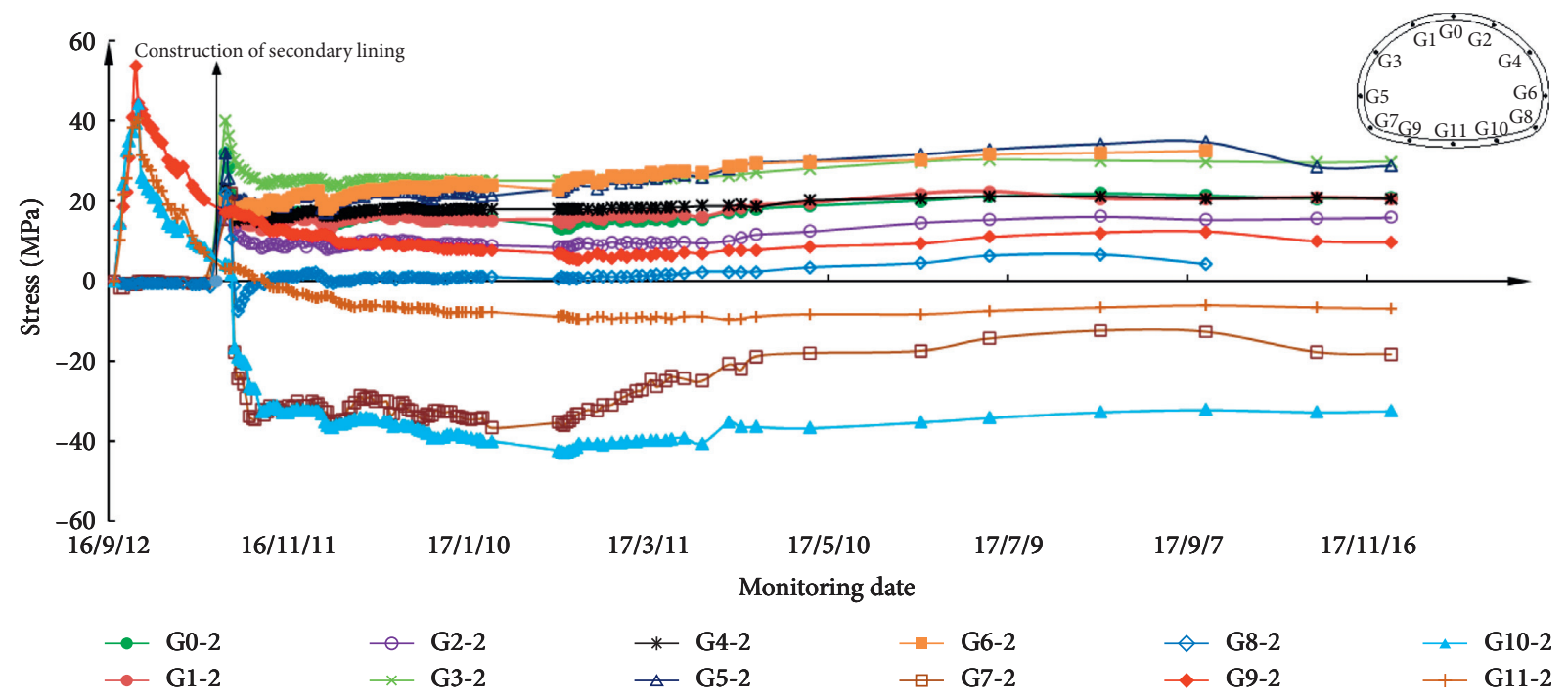

FIGURE 19: Steel stress (inside) time curve of secondary lining in YK2 + 133 section. 


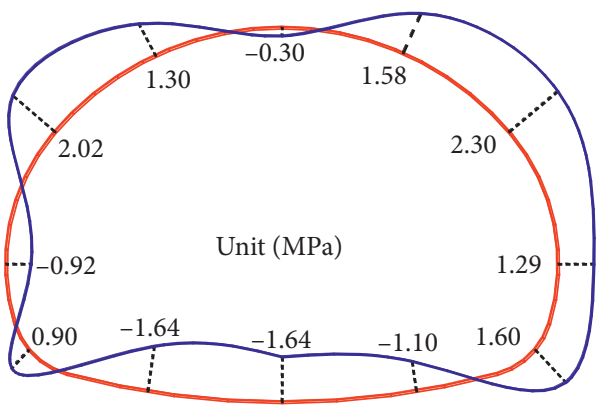

(a)

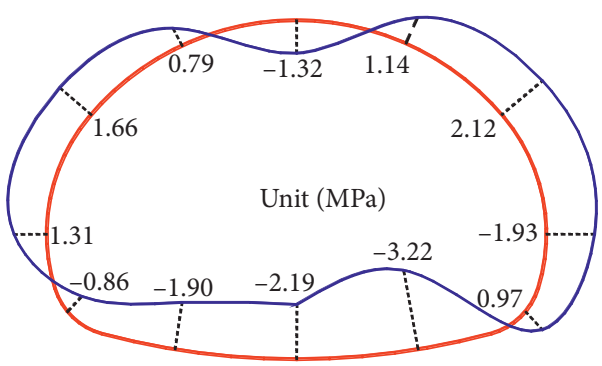

(b)

Figure 20: Stress distribution of secondary lining concrete of YK2 +133 section. (a) Maximum stress value of outside concrete. (b) Maximum stress value of inside concrete.

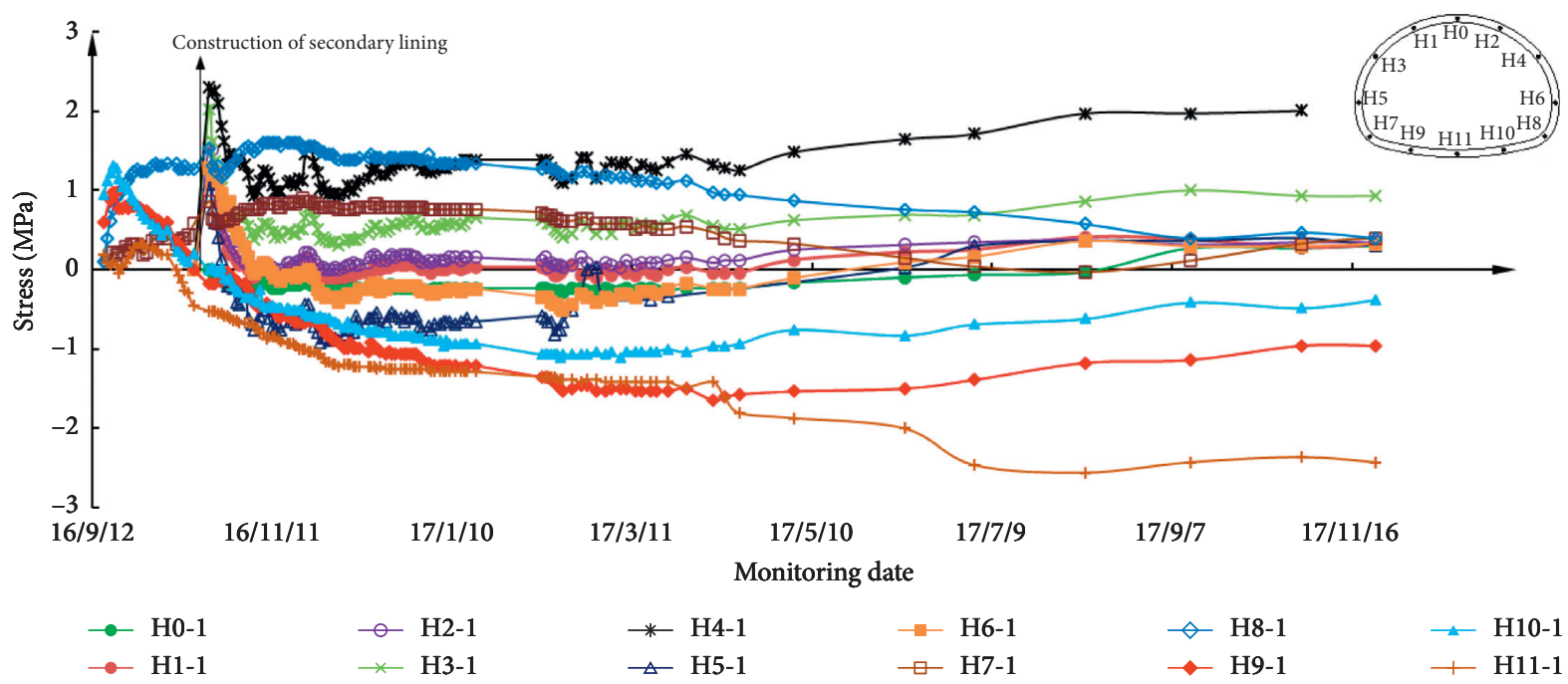

FIGURE 21: Time curve of secondary lining concrete (outside) in YK2 + 133 section.

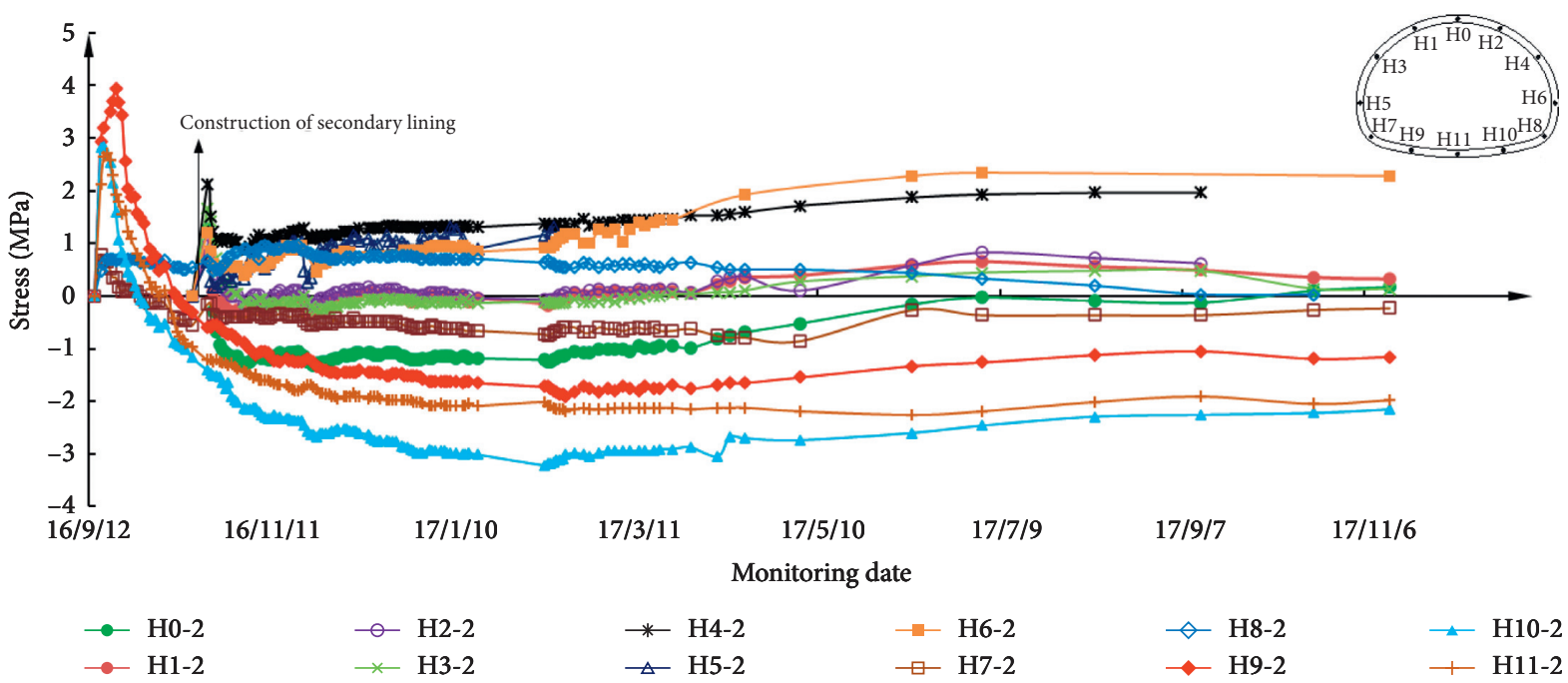

FIgURE 22: Time curve of secondary lining concrete (inside) in YK2 + 133 section. 
mass, and the rock mass was assumed to be elastoplastic material, which would lead to slight differences between the simulation results and field monitoring results in individual parts. The structural stress and the deformation properties are basically consistent with the deformation and mechanical characteristics of support structure presented by the field monitoring data.

\section{Conclusion}

Through analysis of the deformation, mechanical characteristics, and design parameters of the supporting structure of super-large-span highway tunnel, the main conclusions were drawn as follows:

(1) The numerical simulation of tunnel portal of Laohushan tunnel was carried out using MIDAS-GTS to obtain the deformation properties and mechanical behavior under the supporting of $\mathrm{H} 200 \times 200$ steel rib with spacing of $60 \mathrm{~cm}$ and C25 shotcrete with thickness of $30 \mathrm{~cm}$. The results showed that the overall deformation was small, and both shotcrete and steel rib could meet the structural safety requirements.

(2) The primary supporting structure of the tunnel portal of Laohushan tunnel could meet the structural stress requirements by field monitoring. The curvature of the invert was small and the overall shape of tunnel was flat, so the shotcrete was mainly subjected to tension and the tension of the invert was more significant. The steel rib was mainly subjected to compression, and the load was small. The removal of temporary support and the construction of secondary lining have an impact on the structural stress, and the remaining construction procedures have less impact on the primary support. Affected by the section form and hydration heat, the tensile stress of arch and invert of secondary lining of tunnel portal was large. The secondary lining steel was mainly subjected to compression with small value. The overall structural force tended to be stable 30 days after the construction of secondary lining.

(3) The analysis results of the numerical simulation are basically consistent with the deformation and mechanical characteristics of support structure presented by the field monitoring data, which also satisfied the structural safe requirements, indicating that it is reasonable to adopt supporting structure of $\mathrm{H} 200 \times 200$ steel rib with spacing of $60 \mathrm{~cm}$ and C25 shotcrete with thickness of $30 \mathrm{~cm}$ in the construction of super-large-span tunnel portal section.

\section{Data Availability}

The data used to support the findings of this study are available from the corresponding author upon request.

\section{Conflicts of Interest}

The authors declare that they have no conflicts of interest regarding the publication of this paper.

\section{Acknowledgments}

The authors would like to acknowledge the financial support provided by the National Key R\&D Program of China (Grant no. 2018YFB1600100), the National Natural Science Fund Project of China (Grant no. 51978065), the China Postdoctoral Science Foundation (Grant no. 2016M602738), and the Chang Jiang Scholars Program (Grant no. Q2018209).

\section{References}

[1] M. Sharifzadeh, F. Kolivand, M. Ghorbani, and S. Yasrobi, "Design of sequential excavation method for large span urban tunnels in soft ground - niayesh tunnel," Tunnelling and Underground Space Technology, vol. 35, pp. 178-188, 2013.

[2] L. Li, S. Sun, J. Wang et al., "Development of compound EPB shield model test system for studying the water inrushes in karst regions," Tunnelling and Underground Space Technology, vol. 101, p. 103404, 2020.

[3] J. Chen, W. Liu, L. Chen, Y. Luo et al., "Failure mechanisms and modes of tunnels in monoclinic and soft-hard interbedded rocks: a case study," KSCE Journal of Civil Engineering, vol. 24, no. 4, pp. 1357-1373, 2020.

[4] W. Liu, J. Chen, L. Chen, Y. Luo, Z. Shi et al., "Nonlinear deformation behaviors and a new approach for the classification and prediction of large deformation in tunnel construction stage: a case study," European Journal of Environmental And Civil Engineering, pp. 1-29, 2020.

[5] J. Qiu, Y. Lu, J. Lai, Y. Zhang, T. Yang et al., "Experimental study on the effect of water gushing on loess metro tunnel," Environmental Earth Sciences, vol. 79, no. 11, pp. 1-12, 2020.

[6] Y. Luo and J. Chen, "Research status and progress of tunnel frost damage," Journal of Traffic and Transportation Engineering (English Edition), vol. 6, no. 3, pp. 297-309, 2019.

[7] J. Qiu, Y. Lu, J. Lai, C. Guo, and K. Wang, "Failure behavior investigation of loess metro tunnel under local-high-pressure water environment," Engineering Failure Analysis, vol. 115, Article ID 104631, 2020.

[8] Z. Wang, X. Su, H. Lai, Y. Xie, Y. Qin, and T. Liu, "Conception and evaluation of a novel type support in loess tunnels," Journal of Performance of Constructed Facilities, 2020.

[9] C. Shi, C. Cao, and M. Lei, "Construction technology for a shallow-buried underwater interchange tunnel with a large span," Tunnelling and Underground Space Technology, vol. 70, pp. 317-329, 2017.

[10] L. Li, S. Sun, J. Wang et al., "Experimental study of the precursor information of the water inrush in shield tunnels due to the proximity of a water-filled cave," International Journal of Rock Mechanics and Mining Sciences, vol. 130, 2020.

[11] Z. Hu, K. Du, J. Lai, and Y. Xie, "Statistical analysis of influence of cover depth on loess tunnel deformation in NW China," Advances In Civil Engineering, vol. 2019, Article ID 2706976, 12 pages, 2019.

[12] B. Giovanni, J. Sharp, and U. Rabagliati, "Excavation and support optimisation for a large underground storage facility in wak jointed chalk," in Proceedings of the 7th International Congress on Rock Mechanics, Aachen, Deutschland, 1991.

[13] Y. Zhao, H. He, and P. Li, "Key techniques for the construction of high-speed railway large-section loess tunnels," Engineering, vol. 4, no. 2, pp. 254-259, 2018.

[14] Y. Luo, J. Chen, S. Gao, X. Deng, and P. Diao, "Stability analysis of super-large-section tunnel in loess ground 
considering water infiltration caused by irrigation," Environmental Earth Sciences, vol. 76763 pages, 2017.

[15] H. Zhao, Z. Ru, and C. Zhu, "Reliability-based support optimization of rockbolt reinforcement around tunnels in rock masses," Periodica Polytechnica Civil Engineering, vol. 62, no. 1, pp. 250-258, 2018.

[16] P. Lin, Y. Zhou, H. Liu, and C. Wang, "Reinforcement design and stability analysis for large-span tailrace bifurcated tunnels with irregular geometry," Tunnelling and Underground Space Technology, vol. 38, no. 9, pp. 189-204, 2013.

[17] J. Wang, Q. Huo, Z. Song, and Y. Zhang, "Study on adaptability of primary support arch cover method for large-span embedded tunnels in the upper-soft lower-hard stratum," Advances in Mechanical Engineering, vol. 11, no. 1, pp. 1-15, 2019.

[18] M. Wu and L. Huang, "Research on dynamic construction mechanics of four-lane highway tunnel," Rock Mechanics and Rock Engineering, vol. 25, pp. 3057-3062, 2006.

[19] P. L. He, "Research on the orthogonal test of tunnel supporting parameters based on the finite element strength reduction method," Applied Mechanics and Materials, vol. 170173, pp. 1533-1537, 2012.

[20] X. Han, M. Sun, W. Li, and Y. Zhu, "Optimization of section shape and support parameters of tunnel under complicated conditions," Rock and Soil Mechanics, vol. 32, no. 1, pp. 725-731, 2011.

[21] J. Chen, S. Yang, Y. Luo, and M. Wang, "Field test research on elimination of systematic rock bolts in weak rock tunnel," Rock and Soil Mechanics, vol. 32, no. 01, pp. 15-20, 2011.

[22] S.-m. Gao, J.-p. Chen, C.-q. Zuo, W. Wang et al., "Structure optimization for the support system in soft rock tunnel based on numerical analysis and field monitoring," Geotechnical and Geological Engineering, vol. 34, no. 4, pp. 1089-1099, 2016.

[23] Y. Luo and J. Chen, "Mechanical characteristics and mechanical calculation model of tunnel feet-lock bolt in weak surrounding rock," Chinese Journal of Geotechnical Engineering, vol. 35, no. 08, pp. 1519-1525, 2013.

[24] Y. Luo, J. Chen, H. Wang, and P. Sun, "Deformation rule and mechanical characteristics of temporary support in soil tunnel constructed by sequential excavation method," KSCE Journal of Civil Engineering, vol. 21, no. 6, pp. 2439-2449, 2017.

[25] W. Min, J. Lai, J. Qiu, and Y. Zhang, "Numerical analysis of excavation scheme of four lane long-span shallow buried loess tunnel," Journal of PLA University of Science and Technology (Natural Science Edition), vol. 18, no. 1, pp. 36-42, 2017.

[26] D. Zhao, L. Jia, M. Wang, and F. Wang, "Displacement prediction of tunnels based on a generalised Kelvin constitutive model and its application in a subsea tunnel," Tunnelling and Underground Space Technology, vol. 54, pp. 29-36, 2016.

[27] D. Zhang, Q. Fang, P. Li, and L. N. Y. Wong, "Structural responses of secondary lining of high-speed railway tunnel excavated in loess ground," Advances in Structural Engineering, vol. 16, no. 8, pp. 1371-1379, 2013.

[28] Q. Fang, D. Zhang, and L. N. Y. Wong, "Shallow tunnelling method (STM) for subway station construction in soft ground," Tunnelling and Underground Space Technology, vol. 29, pp. 10-30, 2012.

[29] H. Wu, Y. Zhong, W. Xu, W. Shi, X. Shi, and T. Liu, "Experimental investigation of ground and air temperature fields of a cold-region road tunnels in NW China," Advances in Civil Engineering, p. 12, Article ID 4732490, 2020.

[30] H. Li, E. Ma, J. Lai et al., "Tunnelling induced settlement and treament techniques for a loess metro in xi'an," Advances in Civil Engineering, vol. 2020, p. 16, Article ID 1854813, 2020.
[31] X. Wang, J. Lai, S. He, R. Garnes, and Y. Zhang, "Karst geology and mitigation measures for hazards during metro system construction in Wuhan, China," Natural Hazards, vol. 102, no. 3, pp. 1909-1935, 2020.

[32] P. Li, Y. Zhao, and X. Zhou, "Displacement characteristics of high-speed railway tunnel construction in loess ground by using multi-step excavation method," Tunnelling and Underground Space Technology, vol. 51, pp. 41-55, 2016.

[33] T. Zhang, "Mechanical response analysis of four-lane extralarge section and small clearance highway tunnel," Journal of Civil Engineering, vol. 48, pp. 302-305, 2015.

[34] C. Cai, C. Shi, M. Lei et al., "Deformation characteristics and countermeasures of shallow and large-span tunnel undercrossing the existing highway in soft soil: a case study," KSCE Journal of Civil Engineering, vol. 22, no. 8, pp. 3170-3181, 2018.

[35] J. Gong, C. Xia, and H. Zhu, "Optimal analysis of construction scheme for large section and small clear spacing tunnel in Heshang," Geotechnical Mechanics, vol. 30, no. 1, pp. 236-240, 2009.

[36] K. Jiang, C. Xia, and Y. Bian, "Optimum analysis of construction scheme for two-way eight-lane tunnel with small net distance in jointed rock mass," Geotechnical Mechanics, vol. 33, no. 3, pp. 841-847, 2012.

[37] W. Gao, M. Yang, and Q. Bi, "Research on reasonable excavation method of super large section tunnel," in Proceedings of the International Conference on Architectural Science and Technology, Beijing, China, 2010.

[38] D. Zhou, H. Qu, and Y. Cai, "Field Test Study on surrounding rock deformation of large-span tunnel with super large crosssection," Journal of Rock Mechanics and Engineering, vol. 28, no. 9, pp. 1773-1782, 2009, (in Chinese).

[39] S. Li, Z. Tan, and W. Du, "Mechanics effect analysis of small clear distance highway tunnel with extra large section," Journal of Civil Engineering, vol. 50, pp. 292-296, 2017.

[40] C. Xu, C. Xia, and H. Zhu, "Optimum analysis of construction scheme for two-way eight-lane multi-arch tunnel," Journal of Rock Mechanics and Engineering, vol. 28, no. 1, pp. 66-73, 2009, (in Chinese).

[41] S. Zhong, Unified Research Theory of Concrete Filled Steel Tube, Tsinghua University Press, Beijing, China, 2006.

[42] China communications second highway survey and design institute Co., ltd," Design Rules for Highway Tunnels: JTG/T D70-2010, China Communication Press, Beijing, China, 2010.

[43] B. Shen, "Coal mine roadway stability in soft rock: a case study," Rock Mechanics and Rock Engineering, vol. 47, no. 6, pp. 2225-2238, 2014. 